\title{
Consumption of cultural goods and services and time allocation in Brazil
}

Consumo de bens e serviços culturais e alocação de tempo no Brasil

\author{
Ana Flávia Machado \\ Universidade Federal de Minas Gerais \\ André Braz Golgher \\ Universidade Federal de Minas Gerais \\ Sibelle Diniz \\ Universidade Federal de Minas Gerais
}

Luiz Carlos Day Gama

Universidade Federal de Minas Gerais

\begin{abstract}
Consumption of culture is a time intensive activity; therefore, individuals might face not only income constraints, but also time limitations to consume culture. In order to shed light on this topic, the paper combined two different databases to discuss time allocation and the consumption of cultural activities in Brazil. The results suggest that time availability is positively associated with cultural consumption. However, schooling levels and labor market participation are decisive determinants of cultural expenditure. Given these results, the low levels of culture consumption in Brazil are possibly more related to the lack of habit than specifically with the lack of time or monetary resources.
\end{abstract}

\section{Keywords}

cultural economics; cultural consumption; time allocation.

JEL Codes Z10; Z11.

\section{Resumo}

O consumo de cultura é uma atividade intensiva em tempo, de modo que as escolhas ligadas a esta ação são restritas tanto pela renda quanto pelo tempo disponivel para o consumo. Este artigo combina duas bases de dados secundários, a Pesquisa de Orçamentos Familiares e a Pesquisa Nacional por Amostra de Domicílios, para discutir a alocação de tempo e o consumo de bens e serviços culturais no Brasil. Os resultados sugerem que a disponibilidade de tempo é positivamente correlacionada ao consumo cultural. No entanto, nivel de escolaridade e participação no mercado de trabalho são determinantes decisivos do gasto em cultura. Dados esses resultados, os baixos níveis de consumo de cultura no Brasil são possivelmente mais relacionados à ausência de hábito que à ausência de tempo ou de recursos monetários.

\section{Palavras-chave}

economia da cultura; consumo cultural; alocação de tempo.

Códigos JEL Z10; Z11. 


\section{Introduction}

Consumption of culture is a time intensive activity. In order to visit museums and art galleries, attend concerts, watch movies and plays, or even read books, individuals must devote a considerable amount of time exclusively to that activity. Therefore, individuals might face not only income constraints, but also time limitations that restrict their consumption of culture.

Some authors empirically addressed the relationship among culture consumption, income, and time availability (Withers, 1980; Werck; Heyndels, 2007; Zieba, 2009; Muñiz et al., 2011; Lazzaro; Frateschi, 2015). However, studies discussing consumption of culture in Brazil have only analyzed factors associated with expenditures (Diniz; Machado, 2011; Paglioto; Machado, 2012) and have not discussed time allocation, another important feature that should also be addressed while discussing culture consumption.

Therefore, the main objective of this paper is to associate expenditure on cultural activities with time allocated for culture consumption. In order to do so, two different databases are used. The Household Budget Survey (Henceforth: HBS. In Portuguese: POF - Pesquisa de Orçamento Familiar) contains household expenditure information on many types of goods and services, including those associated with culture. Thus, consumption of free cultural services and products, including many traditional events/festivals/ practices could not be analyzed. Hence, in our study only those cultural transactions that occurred through monetary expenditure were included.

The other database used is the National Household Sample Survey (Hereafter: NHSS. In Portuguese: PNAD - Pesquisa Nacional por Amostra de Domicílios), which offers time expenditure information, including time allocated to working, doing domestic chores, and commuting. With the combined use of these two databases, we were able to discuss associations of expenditure and time allocation with the consumption of cultural activities. In order to link the databases, we used synthetic cohorts, as the household sample varies in each survey.

The paper was divided into five sections, including this introduction. The second section presents a theoretical discussion associating culture consumption with income constraints and time allocation, in addition to a literature review on topics empirically addressed here. The next section presents the HBS and NHSS databases, the variables used in our analy- 
sis, and the applied methodology. The empirical results are shown in the fourth section. The last section concludes the paper.

\section{Theoretical models and considerations associating time allocation with culture consumption}

This section presents some classical theoretical models that associated time allocation with culture consumption. The objective is to describe the fundamental ideas driving our empirical analysis. Moreover, we present a literature review with studies addressing topics similar to the one analyzed here in order to contextualize our discussion (Withers, 1980; Werck; Heyndels, 2007; Zieba, 2009; Muñiz et al., 2011; Lazzaro; Frateschi, 2015)

According to Becker (1965), families are no longer just passive utility maximizing agents only buying goods and services in the market, but rather active agents producing goods and services as well as investing in capital building. The author proposed a utility function that considered goods produced by the agents who used as inputs purchased goods, time allocation, personal abilities, training and human capital. That model highlighted that constraints associated with consumption, particularly those related to cultural activities, should not be analyzed solely based on income or expenditure, but also on time availability.

Stigler and Becker (1977) proposed an extension of Becker's model (1965). They argued that individuals tend to show stable preferences, an important feature in utilitarian microeconomic models, which might promote virtuous (or vicious) cycles of culture consumption due to habit building (or the lack of it). Moreover, the authors incorporated different evaluative perspectives that were overlooked by the conventional microeconomic theory, including personal habits and peer effects.

Theoretical models emphasized not only that culture consumption is time intensive, but also that factors related to the life course influence the consumption of cultural goods and services. In this vein, culture consumption should be analyzed from a perspective that includes the opportunity cost of time. For instance, individuals who watch a movie in the cinema are spending time that could be invested in other activities. The model should also incorporate variables associated with habit building and the role of peer effects and social networks. 
In a similar vein, Lévy-Garboua and Montmarquette (2002) studied the demand for live performing arts and cinema. They stated that art consumption increases with exposure over time. They described two classes of theories that predict the dependence of current cultural consumption upon past behavior. They are: rational addiction and learning by consuming. According to the former, the rate of addiction is always positive and deterministic. In learning by consuming theories, consumers alter their taste and behavior through unsystematic experiences of culture consumption, which might have a positive or a negative random impact.

Another factor that might influence culture consumption is the effect of the individual's social relationships, as social networks influence the formation of preferences (Upright, 2004; Lazzaro; Freteschi, 2015). Those papers empirically analyzed this point specifically for couples. While women consistently demonstrate higher levels of attendance with and without their husbands, men are much more likely to be impacted by their wives' behavior. Both papers observed that an individual whose spouse has high levels of arts socialization and education would more likely attend arts events both with and without his or her spouse.

A recent survey analyzed habits associated with time allocation and culture consumption in 25 Brazilian states in $2013^{1}$. The author observed that on weekdays, individuals mostly allocated time to activities such as sleeping, eating, working, doing domestic chores, watching TV, and commuting. On weekends, Brazilians mostly stayed at home, doing activities such as watching TV, eating, and doing domestic chores, or went out to restaurants, to shopping centers, or to non-cultural activities.

Most activities showed little, if any, association with culture consumption. About half of the individuals surveyed did not allocate any time to cultural activities, even on weekends when leisure time is much more available. More than $70 \%$ of the individuals had never gone to an opera, to a music concert, to a ballet, to a dance performance, or to an art exhibition.

Which were the main reasons for this low culture consumption among Brazilians? Contrary to the initial expectations, low income and lack of time were not among them. Individuals stated that they did not like cultural activities, did not find them interesting/important, and/or did not have the habit of consuming this type of activity.

1 See http://www.sesc.com.br/portal/site/publicosdecultura/. 
These results may suggest that Brazilian population does not value culture highly. However, according to Lazzaro and Frateschi (2015), as time is a precious resource, if individuals are allocating time to consume artistic events and culture in general, it is because they truly value them.

Additionally, another factor that should be taken into account while discussing consumption of culture in Brazil is the time spent commuting. Many individuals in metropolitan regions, especially low-income persons who live on the outskirts of these areas, tend to stay close to their house due to limitations in transportation facilities, particularly on weekends. Given that most cultural activities are held close to downtown, this behavior deters the attendance of residents of outlying areas, creating a vicious cycle of low demand for cultural activities.

These results suggest that culture consumption in Brazil is heavily dependent on previously acquired habits, as addressed by the model proposed by Stigler and Becker (1977), and discussed by Morrison and West (1986), Lévy-Garboua and Montmarquette (2002), Upright (2004) and Ateca-Amestoy (2008), and on social relations, as addressed by Upright (2004) and Lazzaro and Frateschi (2015). Paglioto and Machado (2012) empirically applied this perspective to Brazilian data to explain attendance to cultural events outside the household. They used temporal lagged expenditures to observe if there was interdependency of expenditures between periods.

This brief theoretical presentation addressed some of the points we empirically analyzed in this paper. The next section presents the databases, the variables and the methodology applied.

\section{Methodology}

This section presents the two databases used in the empirical analysis, the Household Budget Survey (HBS) and the National Household Sample Survey (NHSS), the selected variables from both databases, and the methodology used in the paper. The presentation was divided into five subsections: databases, variables, definition of the synthetic cohorts, cluster analysis, and multinomial models. 


\subsection{Databases}

We used as databases the 2008/2009 $\mathrm{HBS}^{2}$ and the NHSS of the same years. Both surveys are conducted by the Brazilian Institute of Geography and Statistics ${ }^{3}$ (In Portuguese: IBGE) and are nationally representative.

The former has very detailed information on household expenditures on most types of goods and services in Brazil, including cultural goods and services, as well as socioeconomic and demographic variables. It is the most important survey with information about expenditures in Brazil and it is surveyed every five years. The survey was carried out from May 2008 to May 2009 with a sample size of 55,970 households and about 184,000 individuals. Expenditures are expressed as monetary values, and therefore do not include the consumption of free cultural activities ${ }^{4}$.

The second database, NHSS, is an annual survey containing socioeconomic and demographic information on Brazil's population. It is the most important survey in Brazil addressing general characteristics of the population, second to the Demographic Census in sample size. The database has information on time allocated to working, to doing domestic chores and to commuting 5 . Total NHSS sample sizes were respectively 391,868 and 399,387 individuals in 2008 and 2009.

In order to have similar samples, we initially selected households in the main Brazilian Metropolitan Areas, which are described in table A1 (Appendix). We also harmonized the datasets, selecting in both of them the households whose heads were aged 25 and $a b o v e^{6}$ and had a well-defined schooling level. Those who did not report level of education were dropped. Answers are based on the person of reference, which might or might not be the household head ${ }^{7}$. The final sample sizes for HBS was 7,749 observations and for NHSS was 87,215 observations. Both samples are nation-

2 The most recent available at the time of this research.

3 For further information, see IBGE (2010).

4 Household surveys in Brazil do not contain information on non-monetary consumption, such as attending free activities. Thus, this paper only analyzes the consumption of non-free cultural goods and services purchased in the market.

5 For further information about the database, see IBGE (2009).

6 The age cut off was established as such in order to include those who had time to finish most of their formal education training. Hence they were able to join the labor market at approximately their final schooling level.

7 In both databases, household heads (h.h.) are defined by the residents of the household as the "person responsible for the household", usually the main breadwinner. 
ally representative, including households in all socioeconomic strata. The sample selection used in this paper did not create a sample selection bias.

\subsubsection{Variables}

Table A2 (Appendix) shows the expenditures selected from HBS, associated with direct or indirect/complementary cultural-artistic goods and services. This selection was based on Diniz and Machado (2011) and Paglioto and Machado (2012). Nearly $70 \%$ of the sampled population did not declare any expenditure on culture. As already mentioned, we have restricted our analysis to expenditure, since the database does not include free-of-charge activities ${ }^{8}$ and participation in popular celebrations. Because we considered in this study cultural consumption measured as expenditures on artistic products and services purchased in the market, a more restricted definition of cultural activities and products would implicate in a much smaller sample that could lose its representativeness.

To analyze time allocation we used the NHSS. We selected the two available variables, which are shown in table A3 (Appendix), one for time allocated to the labor market and the other for time allocated to doing domestic chores. We also selected variables from both datasets that are related to time allocation and expenditure on cultural goods and services, which are shown in table A3.

In order to obtain the cultural expenditure and time allocation for the synthetic cohorts - which is explained in more detail in section 3.2, we initially obtained the mean values of the four variables described in table 1 for each cohort: total household expenditure on culture, direct household expenditure on culture, time allocated to working, and time allocated to doing domestic tasks. However, the expenditures were highly skewed variables, as some individuals showed much higher values than the vast majority. Thus, in order to minimize the effects of this data characteristic while determining the profiles in the synthetic cohorts, we used the natural logarithm of these variables. Then, the four variables were normalized, so all ranged from 0 to 1 among all synthetic cohorts. The profiles were obtained by clusters analysis based on these variables, as described in section 3.3. 


\subsection{Definition of synthetic cohorts}

The two databases differ in sampling, although they represent the same years and are nationally representative. In order to link them both, we built the same synthetic cohorts in both, which were based on households' attributes. The use of synthetic cohorts is now a well-established methodology (Deaton, 1985; Verbeek; Nijman, 1992; Devereux, 2007; Verbeek, 2008). We applied a similar methodology; however, this was used, not to link repeated cross-sectional data, but rather, since the synthetic cohorts were the same in both datasets, to create a unique dataset with data from both.

Combining the variables showed in table A3 - except time allocated to working and time allocated to doing domestic chores -, 576 cohorts were obtained. The use of synthetic cohorts to mimic panel data in the absence of longitudinal data has many advantages and it is widely used in many settings. This method, also called the pseudo-panel approach, can provide consistent estimates when the number of observations per cohort is large (Verbeek; Nijman, 1992). Therefore, in these cases, it is tempting to ignore the errors-in-variables estimator proposed by Deaton (1985) and to use synthetic panel as if it were a genuine panel.

Unfortunately, when group sizes are small, the estimates might be biased (Deaton, 1985). Devereux (2007) analyzed the bias for five different estimates associated with male labor supply with 90 cohort-years for different group sizes. The author observed that for three of the estimates the bias was quite small for groups with 100 observations each, and all of them showed a relatively small bias for cohort-years with 500 observations and over. A similar analysis was carried out for females, but with only eight cohort-years. The author observed that the bias was much larger, and the average group size required to keep the bias level low was much bigger, around thousands of observations per group. In another study, Verbeek and Nijman (1992) concluded that sampling errors were not a problem when there were at least 100-200 observations on average per group.

Verbeek (2008) presented some studies that applied pseudo-panels with the number of cohort-years ranging from 70 to 1330. The mean number in each cohort varied from 80 to more than 1000, approximately in an inverse order of that of the number of cohort-years. 
We initially obtained 576 synthetic cohorts for one year. Those groups that had less than 50 observations in the NHSS database were dropped from the analysis in order to decrease sampling error problems, and we ended with 470 cohorts, with an average of over 150 observations in each. Based on the above discussion, this means that bias problems for this dataset are not substantial. However, as we used the same cohorts for the NBS database, which contains far fewer observations, results for this dataset might be biased when each cohort is described separately. Nonetheless, when cohorts are conjointly analyzed descriptively, as in cluster analysis, or in groups associated with different clusters, as in the multinomial logistic models, the bias problems tend to be less remarkable.

\subsection{Cluster analysis}

One of the main objectives of the paper is to verify whether there are specific profiles of cultural expenditure and time allocation. In order to perform this analysis, we applied cluster analysis to the synthetic cohorts. Clustering methods are exploratory statistical procedures that classify the elements of information sets in internally homogeneous groups, allowing the discussion of analytical typologies ${ }^{9}$, in order to find structure in data (Jain, 2010).

There are different procedures and algorithms for clustering data (Jain, 2010). Among the most popular procedures are the hierarchical cluster analysis, K-means cluster, and two-step cluster, each with its own limitations and strengths (Norusis, 2011). This last method is efficient for large data files or for a mixture of continuous and categorical variables (Okazaki, 2006), conditions that do not apply to our database. Hierarchical clustering is a recommended technique for small data sets and for its easiness while examining solutions with different number of clusters (SaintArnaud; Bernard, 2003). Given that our database is not small, like the one used by these last authors, we chose not to use this procedure as our final technique. Therefore, given the nature of our variables and the size of our data set, we chose to use the K-means clustering procedure in our final analysis. However, this technique has the drawback of requiring a previously defined number of clusters.

9 See, for instance, Johnson and Wichern (2001). 
Following Jain (2010), automatically determining the number of clusters has been one of the most difficult problems in data clustering. There are different methods to determine this number, and the Bayes Information Criterion (BIC) and Akaike Information Criterion (AIC) are among the most used.

Given that we could not use the K-means procedure without previously determining the number of clusters, we first ran a two-step cluster to roughly define the number of clusters using these two measures. For both measures, the number of clusters chosen was four. Then, based on these results, we performed the K-means clustering procedure with numbers close to four. Finally, we selected the study with five clusters, as empirical results were poorer for 4 and 6 clusters.

This procedure enabled us to determine sets of homogenous groups of synthetic cohorts, each representing a different profile concerning the four cited variables.

\subsection{Multinomial logistic models}

After defining cultural expenditure and time allocation profiles with cluster analysis, a descriptive and exploratory technique, econometric models were used to verify which of the characteristics used to build the synthetic cohorts were significantly different among the clusters. Given that the dependent variable is categorical, representing the cluster numbers from 1 to 5, we used multinomial logistic models (Greene, 2003). The following equation exemplifies the model:

$$
\ln \left(\frac{P\left(Y_{i}=m\right)}{P\left(Y_{i}=K\right)}\right)=\alpha_{m}+\beta_{m} X_{i}+\varepsilon_{i},
$$

where $P\left(Y_{i}=m\right)$ is the probability that the synthetic cohort belongs to a specific cluster $\mathrm{m}, P\left(Y_{i}=K\right)$ is the probability that the synthetic cohort was classified in the cluster of reference $\mathrm{K}, \alpha_{m}$ is the estimated model's constant, $\beta_{m}$ are the estimated model's coefficients, $X_{i}$ are the synthetic cohort's covariates, and $\varepsilon_{i}$ are the errors. 


\section{Descriptive statistics}

This section presents some descriptive statistics. Initially, household expenditure profiles were analyzed in the selected Brazilian metropolitan areas, using the NBS from 2008/2009. It was observed that only $2.8 \%$ of the average household budget was spent on cultural goods and services. Households located in urban areas spent the majority of their budgets on food, rent, taxes and services, and vehicles and transportation (Golgher, 2015). While $44.6 \%$ of the households did not spend any part of their budget on culture, $25 \%$ spent over one thousand dollars annually.

Table A4 (Appendix) compares households with no cultural expenditure to those that had positive cultural expenditures. First, notice that differences are not remarkable. As already mentioned, women tend to consume more cultural activities than men, but since most female-headed households in Brazil tend to possess less disposable income, the female group is less prevalent in the positive expenditures group. Age is positively related to consumption of culture, as income and time availability, personal tastes and other factors undergo lifetime changes, and older individuals tend to spend more on culture (Upright, 2004; Seaman, 2006; Ateca-Amestoy, 2008).

Schooling and income levels are among the main determinants of cultural consumption (Morrison; West, 1986; Lévy-Garboua; Montmarquette, 2002; Fernández-Blanco et al., 2004; Upright, 2004; Seaman, 2006; AtecaAmestoy, 2006). Since both variables are highly correlated, we chose to include only the former in our analysis. In addition, education is more directly related to cultural capital building. One can see in table A4 (Appendix) that more education is related to higher prevalence of positive expenditure on culture.

Employed individuals might have less time availability and higher opportunity costs for consuming culture than those individuals who are unemployed or retired. In table A4 no significant differences between these groups are observed.

Individuals living in households with small children tend to have less income and time availability. This tendency is especially strong for women (Ringstad; Loyland, 2006; Muñiz et al., 2011; Paglioto; Machado, 2012), whether or not they are married. (Fernández-Blanco, 2004). However, again, when we focus on cultural expenditure, no significant differences arise. Finally, regional differences were very small. 
To summarize: the collection of households with positive expenditures had a larger proportion of male, young, more educated and employed household heads, who lived in childless households or with small children. Similar results have been obtained by Muñiz et al. (2011) and Lazzaro and Frateschi (2015). Notice, however, that the groups showed considerably more similarities than differences.

In order to provide a more detailed analysis, table A5 (Appendix) shows descriptive statistics for quartiles of cultural goods and services expenditures. Some differences that were not clear in the previous table are highlighted here. First, the mean values for expenditure in the quartiles are highly heterogeneous: 0; 63; 398 and 2398 Reals (respectively around $0 ; 27 ; 172$ and 1034 US dollars). Households in the fourth quartile had larger proportions of household heads who were male, aged 36 to 55, with higher levels of formal education, employed, with older children in the household, and living in a metropolitan area in the Southeast region ${ }^{10}$.

Table A6 (Appendix) shows time allocated to working/commuting to work for employed household heads. Males and those aged 25 to 45 tended to spend more time on these activities. The same result was observed for household heads that had between 8 and 11 years of formal education, for those who lived with small children, and for those who lived in the Southeast region.

Table A7 (Appendix) shows time allocated to domestic chores for employed and unemployed/retired household heads. Some groups in the population tended to spend more time doing these activities, such as females, those with lower levels of formal education, those who did not work, and those who lived in households without children. Differences in age and place of residence do not show clear trends.

This section presents descriptions for expenditures and time allocation. Tendencies for time allocated to working/commuting and to domestic chores are very clear. For expenditures, the differences among the population groups are less remarkable. The next subsection further explores these results, linking them with the synthetic cohorts.

10 Brazil's Southeast region has the country's highest purchasing power. One of the reasons is that the nation's largest metropolitan areas are located in this region: São Paulo and Rio de Janeiro. 


\section{Results}

\subsection{Clusters analysis}

The 470 synthetic cohorts were categorized using cluster analysis in five approximately homogenous groups regarding specific combinations of total and direct cultural expenditure and time allocated to working/commuting and to domestic chores. Notice, as already mentioned, that values for each variable ranged from 0 to 1,0 representing the lowest value among the synthetic cohorts and 1 the highest. Therefore, all four variables had a similar influence in the process of constructing the clusters. Table B1 (Appendix) shows the results for the centroids of each cluster regarding each variable.

Table 1 Mean values for each variable in each cluster

\begin{tabular}{l|r|r|r|r|r}
\hline \multirow{2}{*}{ Variable } & \multicolumn{4}{c}{ Cluster } \\
\cline { 2 - 7 } & $\mathbf{1}$ & $\mathbf{2}$ & $\mathbf{3}$ & $\mathbf{4}$ & $\mathbf{5}$ \\
\hline Time allocated to working/commuting (hours) & 43.3 & 40.3 & 0.0 & 0.0 & 42.0 \\
\hline Time allocated to domestic tasks (hours) & 9.7 & 17.3 & 21.2 & 21.7 & 12.3 \\
\hline $\begin{array}{l}\text { Mean total annual household expenditure } \\
\text { on culture (reals R\$) }\end{array}$ & 955.9 & 30.6 & 718.2 & 0.5 & 747.7 \\
\hline $\begin{array}{l}\text { Mean direct annual household expenditure } \\
\text { on culture (reals R\$) }\end{array}$ & 197.8 & 0.0 & 61.6 & 0.1 & 1.0 \\
\hline
\end{tabular}

Source: Own calculation.

Table 1 shows the mean values for each variable in each cluster, which is more illustrative than the cluster's centroids. For instance, the values for time allocated to working/commuting are above 40 hours weekly in clusters 1, 2 and 5, and zero in clusters 3 and 4. These results indicate that the first three mentioned clusters characterized workers, while the last two classified non-workers. Concerning time allocated to domestic chores, clusters 3 and 4 had the highest values, above 20 hours weekly, while cluster 1 and 5 had the lowest, below 13. The mean values for total annual household expenditure in culture varied widely. Three clusters showed higher values, above 700 reals annually, while two showed values close to zero. For mean direct annual household expenditure on culture, cluster 1 had the highest value, and cluster 3 came next, while the others 
showed values close to zero. Similarly to Lazzaro and Frateschi (2015), our results show that time is a precious resource; people who spent more time consuming artistic events and culture in general (cluster 1), spent less time in domestic tasks.

Analyzing all variables conjointly for each cluster, general profiles are straightforwardly determined. Table 2 summarizes the main characteristics of each profile. Cluster 1 represented the household heads who worked, did not spend much time on domestic activities, and had high direct and total expenditures in culture. Cluster 2 described household heads who were employed, spent some time on domestic activities, and had low direct and medium total expenditures on culture. Although they were workers and might have some available income, they did not spend much on culture, possibly due to time scarcity (as they worked and spent a sizable time on domestic chores) and/or to lack of cultural capital building. Cluster 5 characterized workers who spent small amounts of time on domestic activities, with low direct and medium total expenditures on culture. Cluster 5 classified synthetic cohorts with intermediate characteristics when compared to clusters 1 and 2 .

Clusters 3 and 4 characterized non-workers, and in both clusters, the time spent doing domestic activities was higher than in other clusters. Clusters 3 and 4 differed essentially in the total amount spent on culture, high for cluster 3 and low for cluster 4 . This last group did not spend much on culture, probably due to income shortage. Comparing these last two clusters, why are those classified in cluster 3 not showing binding income constraints? Are they already retired or receiving government transfers?

Notice in the last column of the table that the distribution of synthetic cohorts among the clusters was uneven. Cluster 1 characterized 94 cohorts, or $20 \%$ of the total, while clusters 2, 3, 4 and 5 characterized respectively $5.1 \%, 34 \%, 8.5 \%$ and $32.3 \%$ of the total. That is, some features, such as those represented by clusters 3 and 5, classified more synthetic cohorts, while others, such as those of clusters 2 and 4, were rarer.

The previous paragraphs enumerated some of the differences among the clusters. More details are presented in table B2 (Appendix) with descriptive comparisons between the clusters. The following section further analyzes the results of this section with multinomial models. 
Table 2 Main characteristics of the clusters

\begin{tabular}{l|l|r}
\hline Cluster & Main characteristics of the clusters & $\begin{array}{r}\text { Number of synthetic } \\
\text { cohorts classified in } \\
\text { the cluster }\end{array}$ \\
\hline 1 & $\begin{array}{l}\text { Household heads who were employed, did not spend much time } \\
\text { on domestic activities, and had high direct and total expenditures } \\
\text { on culture. }\end{array}$ & 94 \\
\hline 2 & $\begin{array}{l}\text { Household heads who were employed, spent some time on } \\
\text { domestic activities, and had low direct and medium total } \\
\text { expenditures on culture. }\end{array}$ & 160 \\
\hline 3 & $\begin{array}{l}\text { Non-workers who spent a lot of time on domestic activities, } \\
\text { with medium to low direct and high total expenditures on culture. }\end{array}$ \\
\hline 4 & $\begin{array}{l}\text { Non-workers who spent a lot of time on domestic activities, } \\
\text { with low direct and total expenditures on culture. }\end{array}$ \\
\hline 5 & $\begin{array}{l}\text { Workers who spent a short time on domestic activities, } \\
\text { with low to medium direct and high total expenditures on culture. }\end{array}$ \\
\hline
\end{tabular}

Source: Own calculation.

\subsection{Multinomial logistic models}

The multinomial logistic models compare these same clusters from a different perspective. The objective is to verify if the differences among clusters regarding the variables used to build them are statistically significant. For the sake of brevity, we selected some comparisons with a direct theoretical meaning. For instance, we compared clusters 1, 2, and 5, as all three represent workers. Clusters 3 and 5 are contrasted because they have the same expenditure profile, although they differ in other aspects. For this same reason, clusters 2 and 4 are compared. Finally, we contrasted clusters 3 and 4 because both are for non-workers. Table 3 shows the odds-ratio for the same variables presented in table B2.

The first comparison is between clusters 1 and 2. Notice, as described in tables 1 and 2, that the main differences between these clusters is the fact that, although both are for workers, the cohorts classified in cluster 2 spent more time on domestic activities and much less on culture. Among the explanatory variables, four variables were significant at $5 \%$. The propensity to belong to cluster 2 was much greater for females than for males. Other features that greatly increased the propensity to belong to cluster 2 
were being in the 56-and-over age bracket, and having from 8 to 10 years of formal education, levels lower than a high school diploma, but higher than elementary level. Place of residence did not show any significant coefficient. For household composition, those living in households with at least one older son/daughter had a smaller propensity to belong to cluster 2. That is, females, aged 56 and over, with low educational levels and with no child aged 14 and above in the household, spent more time on domestic activities and less on culture than, for instance, highly educated young men, typically from cluster 1 .

The next comparison is between clusters 1 and 5 . The main difference between these clusters presented in table 1 and 2 is the dissimilarity in direct expenditure, which is much higher in the first cluster. The model in table 3 has only three significant variables, which are for sex and place of residence. That is, age, educational level and household composition were not significantly correlated with the differences between clusters 1 and 5 . Women who did not live in the Southeast region had a greater propensity to be in cluster 5 . This result suggests that men spent more on activities classified as direct, especially if they lived in the Southeast region.

The third comparison is between clusters 2 and 5. The two profiles are for workers and they differ mostly in the amount of domestic activities and cultural expenditures, which are respectively higher and lower in the first cluster. The results are quite similar to those of the comparison between clusters 1 and 2: namely, unskilled older working women tend to spend more time doing domestic activities and to spend less on culture than qualified young working men. The odds-ratio for sex, for the age group of 56 and above and for at least some tertiary education were all much lower or much higher than unity, suggesting that differences in propensity to belong to the different clusters are greater for these variables.

The next comparison is between clusters 3 and 5 . Notice that the main difference between them is that the first group comprises non-workers who spend significant amounts of time on domestic activities and the second comprises workers who spend less time on domestic chores. Expenditures on culture are rather similar. Older individuals with lower levels of formal education had a greater likelihood of being in cluster 3. They are probably retired or beneficiaries of government benefits, subsidies and transfers, as income constraints seem not to be so decisive. Notice that this is the only comparison where the gender variable was not significant. 
The fifth comparison is between clusters 2 and 4 . We can observe that they are very particular profiles with few cohorts, as shown in table 2 . As previously described, both have low levels of culture consumption, and differ mostly because the first represents workers and the second represents non-workers. Older females had a greater likelihood of being in cluster 2 ; i.e., they work, but probably have constraints in terms of money, time and habits, which limits their consumption of culture. Cluster 4 characterizes non-working men who live in Brazil's poorest regions, probably with income constraints for consuming culture.

Finally, the last comparison is between clusters 3 and 4, both containing non-workers. The main difference between them is that the amount spent by cluster 3 on culture is much higher. Being an older woman greatly increased the odds of belonging to cluster 3 , suggesting no time constraint and some cultural consumption habits.

Table 3 Odds ratios for multinomial models with the clusters numbers as dependent variable

\begin{tabular}{|c|c|c|c|c|c|c|}
\hline \multirow{3}{*}{ Variables } & \multicolumn{6}{|c|}{ Comparisons } \\
\hline & Cluster 2 & Cluster 5 & Cluster 2 & Cluster 3 & Cluster 2 & Cluster 3 \\
\hline & \multicolumn{2}{|c|}{ Cluster 1 (reference) } & \multicolumn{2}{|c|}{ Cluster 5 (reference) } & \multicolumn{2}{|c|}{ Cluster 4 (reference) } \\
\hline Male & $0.07^{* *}$ & $0.38 * *$ & $0.18^{* *}$ & 0.83 & $0.10^{* *}$ & $0.44^{* *}$ \\
\hline \multicolumn{7}{|l|}{ Age categories } \\
\hline 25 to 35 & Ref. & Ref. & Ref. & Ref. & Ref. & Ref. \\
\hline 36 to 45 & 0.59 & 1.28 & 0.46 & 1.03 & 0.24 & 0.53 \\
\hline 46 to 55 & 2.43 & 0.99 & 2.47 & $2.05^{* *}$ & 1.50 & 1.25 \\
\hline 56 and over & $10.6^{* *}$ & 1.24 & $8.52^{* *}$ & $3.07^{* *}$ & $49.2^{* *}$ & $17.7^{* *}$ \\
\hline \multicolumn{7}{|l|}{ Educational level } \\
\hline 0 to 7 & Ref. & Ref. & Ref. & Ref. & Ref. & Ref. \\
\hline 8 to 10 & $3.77^{* *}$ & 1.59 & 2.37 & 0.71 & 1.83 & 0.55 \\
\hline 11 & 0.74 & 1.37 & 0.54 & 0.63 & 0.38 & $0.45^{*}$ \\
\hline 12 and above & 0.16 & 1.12 & $0.14^{*}$ & $0.51^{* *}$ & 0.70 & 2.54 \\
\hline \multicolumn{7}{|l|}{ Regions } \\
\hline Southeast & Ref. & Ref. & Ref. & Ref. & Ref. & Ref. \\
\hline Northeast/North & 1.22 & $1.83^{*}$ & 0.67 & 0.77 & 0.59 & 0.69 \\
\hline South/Federal District & 1.05 & $2.19 * *$ & 0.48 & 0.79 & 0.69 & 1.14 \\
\hline \multicolumn{7}{|l|}{ Household composition } \\
\hline No children & Ref. & Ref. & Ref. & Ref. & Ref. & Ref. \\
\hline All below 14 & 1.41 & 0.74 & 1.90 & 0.96 & 1.11 & 0.56 \\
\hline
\end{tabular}




\begin{tabular}{l|lr|r|r|rrr}
\hline \multirow{2}{*}{ Variables } & \multicolumn{4}{c}{ Comparisons } \\
\cline { 2 - 8 } & Cluster 2 & Cluster 5 & Cluster 2 & Cluster 3 & Cluster 2 & Cluster 3 \\
\cline { 2 - 7 } & \multicolumn{1}{|c}{ Cluster 1 (reference) } & Cluster 5 & (reference) & Cluster 4 (reference) \\
\hline At least one 14 and above & $0.23^{* *}$ & 0.72 & $0.32^{*}$ & 1.06 & 0.45 & 1.48 \\
\hline
\end{tabular}

Source: Own calculation.

Notes: ** significant at $5 \%,{ }^{*}$ significant at $10 \%$.

\section{Final remarks and conclusion}

The paper associates culture consumption and time allocation. Individuals who allocated less than 30 hours weekly to working and to domestic tasks spent a mean value of approximately 750 reals (Roughly US\$215) ${ }^{11}$ on cultural products and services. On the other hand, those who allocated more than 60 hours to those two activities spent even less, around 425 reals. Those who allocated between 40 and 50 hours, spent much more than all other groups, with approximately a mean value of 1040 reals.

The consumption of culture is a time intensive activity; therefore, individuals might face not only income constraints, but also time limitations on consuming culture. We built synthetic cohorts with the intention of linking both databases. Then these cohorts were grouped, with the use of cluster analysis, in cultural consumption and time allocation profiles. Finally, the main determinants influencing the propensity to belong to each profile with multinomial models were analyzed.

The results suggest that time availability is positively associated with cultural consumption, as these activities are time intensive. However, besides the availability of time, schooling levels and labor market participation are decisive determinants of expenditure on cultural services, suggesting the mutual influence of income and time availability. Therefore, individuals who work for extended hours might have money, but may lack the time necessary to consume cultural services and products. On the other hand, those with time availability may face income constraint to consume culture. However, contrary to the initial expectations, income and lack of time were not among the significant limiting factors. Price magnitudes vary when comparing a cinema or a museum ticket with an opera 
ticket or purchasing a sculpture. Thus, different socio strata can potentially consume different cultural products, which are more appropriate with a specific income and time constraints. Although culture consumption habits were not considered in our empirical analysis, just expenditures, the results in this paper corroborate the results of SESC (page note number 1), which observed that individuals declared that they neither liked cultural activities nor found them interesting or important. Besides, for those at the bottom of the socioeconomic pyramid, the habit of culture consumption was still strongly linked to popular celebrations, such as samba, frevo, maracatu or congado performances, or free cultural activities promoted by public authorities, activities that were not analyzed here. Given these results, the low level of culture expenditure in Brazil is possibly more related to the absence of habit to consume paid cultural activities and the vicious cycle created by the low demand for paid cultural activities than specifically to lack of time or monetary resources. These results suggest that the model proposed by Stigler and Becker (1977) might be more appropriate to describe the Brazilian reality than the model suggested by Becker (1965).

Thus, public policies that promote educational activities in museums or cultural centers, especially those focusing on young individuals from low income families, might have a remarkable multiplying effect on culture consumption both for children and their parents, as they might be habitbuilding activities.

Other policies might have similar effects, such as the existing one that facilitates culture consumption by the working class. Formally documented workers earning less than five Brazilian Minimum Wages are entitled to receive 50 reals (US\$14.3 dollars) per month from the government to invest in cultural activities. This policy enhances their access to courses in arts, cinema, circus, dance, photography, music, drama and literature. Moreover, the policy increases their contact with crafts, cinema, documentaries, movies, musicals, sculpture, performances, shows, theaters, circuses, etc.

\section{References}

ATECA-AMESTOY, V. Determining heterogeneous behavior for theater attendance. Journal of Cultural Economics, Akron, v. 32, n. 2, p. 127-151, Jun. 2008.

BECKER, G.S. A theory of the allocation of time. Economic Journal, 75, p. 493-517, set. 1965. 
DEATON, A. Panel data from time series of cross-sections. Journal of Econometrics, v. 30, p. 109-126, 1985.

DEVEREUX, P. J. Small-sample bias in synthetic cohort models of labor supply. Journal of Applied Econometrics, v. 22, n. 4, p. 839-848, 2007.

DINIZ, S. C.; MACHADO, A. F. Analysis of the Consumption of Artistic-Cultural Goods and Services in Brazil. Journal of Cultural Economics, v. 35, p. 1-18, 2011.

FERNÁNDEZ-BLANCO, V.; PRIETO-RODRÍGUEZ, J.; OREA-SÁNCHEZ, L. Movie enthusiasts versus cinemagoers in Spain: A latent class model approach. In: 13th ACEI Conference. University of Illinois at Chicago, 2004.

GREENE, W. Econometric analysis. Fifth edition, Upper Saddle River: Prentice Hall, 2003.

GOLGHER, A. Multidimensional poverty in Brazil: income, assets and expenses. International Journal of Social Economics, v. 43, n. 1, p.19-38, 2015.

IBGE. Pesquisa Nacional por Amostra de Domicílios, v. 30, Rio de Janeiro, 2009.

IBGE. Pesquisa de orçamentos familiares 2008-2009: despesas, rendimentos e condições de vida, Rio de Janeiro, 2010.

JAIN, A. Data clustering: 50 years beyond K-means. Pattern Recognition Letters. v.31, n. 8, p. 651-666, June 2010.

JOHNSON, R. A.; WICHERN, D. W. Applied Multivariate Statistical Analysis. 5th ed. Prentice Hall, Englewood Cliffs, NJ, 2001.

LAZZARO, E.; FRATESCHI, C. Couples'arts participation: assessing individual and joint time use. Journal of Cultural Economics, December 2015.

LÉVY-GARBOUA, L., MONTMARQUETTE, C. The demand for the arts. Scientific Series. Cirano and Departament of Economics, University of Montreal, 2002.

MORRISON, W.G.; WEST, E. G. Child Exposure to the Performing Arts: The Implications for Adult Demand. Journal of Cultural Economics, v. 10, p. 17-24, 1986.

MUÑIZ, C.; RODRÍGUEZ, P.; SUÁREZ, M. J. The allocation of time to sports and cultural activities: an analysis of individual decisions. International Journal of Sport Finance, v.6, n.3, p. 245-264, 2011.

NORUSIS, M. J. IBM SPSS statistics 19 guide to data analysis. Upper Saddle River, New Jersey: Prentice Hall, 2011.

PAGLIOTO, B.; MACHADO, A. F. Perfil dos frequentadores de atividades culturais: o caso nas metrópoles brasileiras. Estudos Econômicos (São Paulo. Impresso), v. 42, p. 701-730, 2012 .

OKAZAKI, S. What do we know about mobile Internet adopters? A cluster analysis. Information \& Management, 43, p. 127-141, 2006.

RINGSTAD, V.; LOYLAND, K. The demand for books estimated by means of consumer survey data. Journal of Cultural Economics, Akron, v. 30, n. 2, p. 141-155, Set. 2006.

SAINT-ARNAUD, S.; BERNARD, P. Convergence or Resilience? A Hierarchical Cluster Analysis of the Welfare Regimes in Advanced Countries. Current Sociology, v. 51, n. 5, p. 499-527, September 2003. 
SEAMAN, B. A. Empirical studies of demand for the performing arts. Handbook of the economics of art and culture, 1, p. 415-472, 2006.

STIGLER, G. J.; BECKER, G. S. De gustibus non est disputandum. American Economic Review, Nashville, v. 67, n.2, p. 76-90, Mar. 1977.

UPRIGHT, C. B. Social Capital and Cultural Participation: Spousal Influences on Attendance at Arts Events. Poetics, v. 32, p. 129-143, 2004.

VERBEEK, M.; NIJMAN, T. Can cohort data be treated as genuine panel data? Empirical economics, v. 17, n. 1, p. 9-23, 1992.

VERBEEK, M. Pseudo-panels and repeated cross-sections. In: The econometrics of panel data, $\mathrm{p}$. 369-383, Springer Berlin Heidelberg, 2008.

WERCK, K; HEYNDELS, B. Programmatic choices and the demand for theatre: the case of Flemish theatres. Journal of Cultural Economics, v. 31, p. 25-41, Jan. 2007.

WITHERS, G. A. Unbalanced growth and the demand for performing arts: an econometric analysis. Southern Economic Journal, v. 46, p. 735-742, 1980.

ZIEBA, M. Full-income and Price Elasticities of Demand for German Public Theatre. Journal of Cultural Economics, v. 33, p. 85-108, Mar. 2009.

\section{About the author}

Ana Flávia Machado - afmachad@cedeplar.ufmg.br

Cedeplar/UFMG, Belo Horizonte, Minas Gerais.

AndréBrazGolgher-agolgher@cedeplar.ufmg.br

Cedeplar/UFMG, Belo Horizonte, Minas Gerais.

Sibelle Diniz - sibelled@cedeplar.ufmg.br

Cedeplar/UFMG, Belo Horizonte, Minas Gerais.

LuizCarlos Day Gama - lgama@cedeplar.ufmg.br

Cedeplar/UFMG, Belo Horizonte, Minas Gerais.

\section{About the article}

Submission received on November 12, 2015. Approved for publication on November 08, 2016. 


\section{Appendix A: Variables and descriptive statistics}

Table A1 Metropolitan areas by regions

\begin{tabular}{ll}
\hline Region & Metropolitan Areas \\
\hline North & Belém \\
\hline Northeast & Fortaleza, Recife and Salvador \\
\hline Southeast & Belo Horizonte, Rio de Janeiro and São Paulo \\
\hline South & Curitiba and Porto Alegre \\
\hline Midwest & Federal District \\
\hline
\end{tabular}

Table A2 Cultural-artistic goods and services classification used for estimating cultural expenditures in the 2008/2009 Households Budget Survey

\begin{tabular}{|c|c|c|}
\hline Classification & Group & Products \\
\hline \multirow[t]{4}{*}{ Direct } & $\begin{array}{l}\text { Visits to museums, expositions, } \\
\text { theaters, dance performances, operas, } \\
\text { shows, cinemas and circus }\end{array}$ & $\begin{array}{l}\text { Tickets to museums, expos \& exhibits, } \\
\text { theaters, dance performances, operas, } \\
\text { shows, cinemas and circuses }\end{array}$ \\
\hline & Reading articles & Non-didactic books \\
\hline & Audio and video objects & $\begin{array}{l}\text { Cassettes, videocassettes, LP records, } \\
\text { CDs and DVDs }\end{array}$ \\
\hline & Decorative items & $\begin{array}{l}\text { Sculptures, paintings and decorative } \\
\text { crafts }\end{array}$ \\
\hline \multirow[t]{9}{*}{$\begin{array}{l}\text { Indirect or } \\
\text { complementary }\end{array}$} & Reading articles & $\begin{array}{l}\text { Newspapers, magazines, musical } \\
\text { brochures and journal subscriptions }\end{array}$ \\
\hline & Audio and video objects & Cassettes and video club fees / taxes \\
\hline & Musical instruments and accessories & $\begin{array}{l}\text { Musical instruments and accessories, } \\
\text { such as microphones, speakers, etc. }\end{array}$ \\
\hline & Courses & $\begin{array}{l}\text { Courses in dance, music, drawing, } \\
\text { design, painting and drama }\end{array}$ \\
\hline & Visits to nightclubs & Tickets, rent and art endowments \\
\hline & Household services & Internet and cable TV \\
\hline & Home-use utensils & $\begin{array}{l}\text { TVs, stereos, dish-antennas, videos, } \\
\text { computers, DVDs, radios, etc. }\end{array}$ \\
\hline & Furniture associated with cultural goods & $\begin{array}{l}\text { Tables / desks for TV sets, stereos, } \\
\text { computers, etc. }\end{array}$ \\
\hline & Others & $\begin{array}{l}\text { Photo services (except for family } \\
\text { ceremonies) and carnival costumes }\end{array}$ \\
\hline
\end{tabular}

Source: Households Budget Survey 2008/2009. 
Table A3 Time Allocation and household variables

\begin{tabular}{|c|c|c|c|c|c|c|}
\hline Variable & Description & Category & $\begin{array}{l}\text { Mean } \\
\text { NHSS }\end{array}$ & $\begin{array}{r}\text { Mean } \\
\text { HBS }\end{array}$ & Min & Max \\
\hline \multirow[t]{5}{*}{ Time_work } & \multirow{5}{*}{$\begin{array}{l}\text { Time allocated } \\
\text { to working } \\
\text { (hours per week) }\end{array}$} & Less than 35 hours & 0.16 & & 0 & 1 \\
\hline & & From 35 to 40 & 0.32 & & 0 & 1 \\
\hline & & From 40 to 45 & 0.17 & & 0 & 1 \\
\hline & & From 45 to 50 & 0.18 & & 0 & 1 \\
\hline & & 50 and above & 0.16 & & 0 & 1 \\
\hline \multirow[t]{5}{*}{ Time_dom } & \multirow{5}{*}{$\begin{array}{l}\text { Time allocated } \\
\text { to doing } \\
\text { domestic chores } \\
\text { (hours per week) }\end{array}$} & Less than 7 hours & 0.49 & & 0 & 1 \\
\hline & & From 7 to 14 & 0.17 & & 0 & 1 \\
\hline & & From 14 to 21 & 0.14 & & 0 & 1 \\
\hline & & From 21 to 28 & 0.50 & & 0 & 1 \\
\hline & & 28 and above & 0.16 & & 0 & 1 \\
\hline Gender & $\begin{array}{l}\text { Gender of } \\
\text { household head }\end{array}$ & Female & 0.40 & 0.35 & 0 & 1 \\
\hline \multirow[t]{4}{*}{ Age } & \multirow{4}{*}{$\begin{array}{l}\text { Age group of } \\
\text { household head }\end{array}$} & 25 to 35 & 0.21 & 0.22 & 0 & 1 \\
\hline & & 36 to 45 & 0.24 & 0.25 & 0 & 1 \\
\hline & & 46 to 55 & 0.23 & 0.23 & 0 & 1 \\
\hline & & 56 and over & 0.31 & 0.31 & 0 & 1 \\
\hline \multirow[t]{4}{*}{ Education } & \multirow{4}{*}{$\begin{array}{l}\text { Schooling level of } \\
\text { household head }\end{array}$} & Less than 8 years & 0.42 & 0.46 & 0 & 1 \\
\hline & & From 8 to 10 & 0.15 & 0.15 & 0 & 1 \\
\hline & & High School & 0.29 & 0.22 & 0 & 1 \\
\hline & & More than High School & 0.14 & 0.17 & 0 & 1 \\
\hline Work & $\begin{array}{l}\text { Working status of } \\
\text { household head }\end{array}$ & Employed & 0.68 & 0.75 & 0 & 1 \\
\hline \multirow[t]{3}{*}{ Child } & \multirow{3}{*}{$\begin{array}{l}\text { Children in the } \\
\text { household }\end{array}$} & No children & 0.32 & 0.34 & 0 & 1 \\
\hline & & All children under age 14 & 0.25 & 0.24 & 0 & 1 \\
\hline & & At least one child over age 14 & 0.42 & 0.42 & 0 & 1 \\
\hline \multirow[t]{3}{*}{ Residence } & \multirow{3}{*}{$\begin{array}{l}\text { Place of } \\
\text { residence }\end{array}$} & MA from North or Northeast & 0.20 & 0.21 & 0 & 1 \\
\hline & & MA from Southeast & 0.63 & 0.63 & 0 & 1 \\
\hline & & MA from South or Federal District & 0.17 & 0.16 & 0 & 1 \\
\hline
\end{tabular}

Source: National Household Sample Survey 2008/2009 and Households Budget Survey 2008/2009.

Note: MA stands for Metropolitan Area. 
Table A4 Household characteristics by total cultural expenditure

\begin{tabular}{|c|c|c|c|}
\hline & $\begin{array}{r}\text { Zero } \\
\text { expenditure }\end{array}$ & $\begin{array}{r}\text { Positive } \\
\text { expenditure }\end{array}$ & All \\
\hline \multicolumn{4}{|l|}{ Gender of h.h. } \\
\hline Male & 65.2 & 68.7 & 65.4 \\
\hline Female & 34.8 & 31.3 & 34.6 \\
\hline \multicolumn{4}{|l|}{ Age of h.h. } \\
\hline From 25 to 35 & 21.8 & 24.5 & 21.9 \\
\hline From 36 to 45 & 24.6 & 23.5 & 24.5 \\
\hline From 46 to 55 & 23.0 & 25.2 & 23.1 \\
\hline 56 and over & 30.7 & 26.8 & 30.5 \\
\hline \multicolumn{4}{|l|}{ Schooling level of $h . h$. } \\
\hline Less than 8 years & 47.0 & 39.4 & 46.6 \\
\hline From 8 to 10 & 15.1 & 18.1 & 15.2 \\
\hline High school & 21.7 & 25.4 & 21.9 \\
\hline Beyond high school & 16.2 & 17.1 & 16.3 \\
\hline \multicolumn{4}{|l|}{ Working status of h.h. } \\
\hline Employed & 75.0 & 77.9 & 75.2 \\
\hline Unemployed or Retired & 25.0 & 22.1 & 24.8 \\
\hline \multicolumn{4}{|l|}{ Household Children } \\
\hline No children & 32.9 & 34.1 & 33.0 \\
\hline All under 14 & 23.4 & 25.7 & 23.5 \\
\hline At least one over 14 & 43.7 & 40.2 & 43.6 \\
\hline \multicolumn{4}{|l|}{ Place of residence } \\
\hline North and Northeast regions & 21.0 & 22.0 & 21.1 \\
\hline Southeast regions & 62.5 & 63.8 & 62.5 \\
\hline South region and Federal District & 16.5 & 14.2 & 16.4 \\
\hline
\end{tabular}

Source: National Budget Survey of 2008/2009. 
Table A5 Household characteristics by quartile of total cultural expenditure

\begin{tabular}{|c|c|c|c|c|c|}
\hline & $\begin{array}{r}1^{\circ} \\
\text { quartile }\end{array}$ & $\begin{array}{r}2^{\circ} \\
\text { quartile }\end{array}$ & $\begin{array}{r}3^{\circ} \\
\text { quartile }\end{array}$ & $\begin{array}{r}4^{\circ} \\
\text { quartile }\end{array}$ & All \\
\hline \multicolumn{6}{|l|}{ Gender of h.h. } \\
\hline Male & 62.12 & 66.36 & 65.93 & 70.42 & 65.38 \\
\hline Female & 37.88 & 33.64 & 34.07 & 29.58 & 34.62 \\
\hline \multicolumn{6}{|l|}{ Age of h.h. } \\
\hline From 25 to 35 & 20.13 & 29.37 & 26.8 & 18.55 & 21.91 \\
\hline From 36 to 45 & 20.53 & 25.41 & 27.13 & 28.76 & 24.5 \\
\hline From 46 to 55 & 22.16 & 20.52 & 22.41 & 25.84 & 23.05 \\
\hline 56 and over & 37.18 & 24.7 & 23.66 & 26.84 & 30.54 \\
\hline \multicolumn{6}{|l|}{ Household Children } \\
\hline No children & 38.03 & 28.65 & 29.55 & 28.38 & 32.99 \\
\hline All under 14 & 21.31 & 25.89 & 26.62 & 23.63 & 23.47 \\
\hline At least one over 14 & 40.66 & 45.47 & 43.83 & 47.99 & 43.55 \\
\hline \multicolumn{6}{|l|}{ Schooling level of h.h. } \\
\hline Less than 8 years & 52.86 & 58.15 & 50.91 & 28.75 & 46.64 \\
\hline From 8 to 10 & 15.52 & 17.51 & 17.17 & 12.16 & 15.2 \\
\hline High school & 21.29 & 17.32 & 22.43 & 23.42 & 21.89 \\
\hline Beyond high school & 10.33 & 7.02 & 9.49 & 35.67 & 16.28 \\
\hline \multicolumn{6}{|l|}{ Place of residence } \\
\hline North and Northeast regions & 20.62 & 30.71 & 27.39 & 13.49 & 21.08 \\
\hline Southeast regions & 63.01 & 56.35 & 55.63 & 69.88 & 62.52 \\
\hline South region and Federal District & 16.37 & 12.94 & 16.98 & 16.63 & 16.4 \\
\hline \multicolumn{6}{|l|}{ Working status of h.h. } \\
\hline Employed & 69.4 & 78.84 & 79.61 & 80.21 & 75.17 \\
\hline Unemployed or Retired & 30.6 & 21.16 & 20.39 & 19.79 & 24.83 \\
\hline Mean value for the quartiles & 0 & 62.69 & 397.55 & 2397.82 & 702.03 \\
\hline Upper value for the quartiles & 0 & 107 & 842.93 & 9932.8 & - \\
\hline
\end{tabular}

Source: National Budget Survey of 2008/2009. 
Table A6 Time allocated to working/commuting for employed household heads

\begin{tabular}{|c|c|c|c|c|c|}
\hline & Below 35 & $\begin{array}{r}\text { From } 36 \\
\text { to } 40\end{array}$ & $\begin{array}{r}\text { From } 40 \\
\text { to } 45\end{array}$ & $\begin{array}{r}\text { From } 45 \\
\text { to } 50\end{array}$ & $\begin{array}{r}50 \text { and } \\
\text { above }\end{array}$ \\
\hline \multicolumn{6}{|l|}{ Gender of h.h. } \\
\hline Male & 41.32 & 68.81 & 77.07 & 76.89 & 76.75 \\
\hline Female & 58.68 & 31.19 & 22.93 & 23.11 & 23.25 \\
\hline \multicolumn{6}{|l|}{ Age of h.h. } \\
\hline From 25 to 35 & 18.04 & 26.19 & 32.41 & 28.76 & 26.66 \\
\hline From 36 to 45 & 24.61 & 30.53 & 33.76 & 33.07 & 31.94 \\
\hline From 46 to 55 & 26.61 & 28.15 & 24.02 & 25.39 & 27 \\
\hline 56 and over & 30.74 & 15.13 & 9.82 & 12.78 & 14.4 \\
\hline \multicolumn{6}{|l|}{ Schooling level of h.h. } \\
\hline Less than 8 years & 43.04 & 28.32 & 33.75 & 38.43 & 36.09 \\
\hline From 8 to 10 & 13.38 & 14.75 & 17.79 & 18.67 & 17.62 \\
\hline High school & 26.06 & 35.28 & 36.9 & 32.36 & 31.2 \\
\hline Beyond high school & 17.51 & 21.65 & 11.56 & 10.55 & 15.09 \\
\hline \multicolumn{6}{|l|}{ Household Children } \\
\hline No children & 32.68 & 29.75 & 26.3 & 27.21 & 27.16 \\
\hline All under 14 & 22.02 & 30.27 & 37.16 & 35.01 & 32.96 \\
\hline At least one over 14 & 45.3 & 39.98 & 36.54 & 37.79 & 39.88 \\
\hline \multicolumn{6}{|l|}{ Place of residence } \\
\hline North and Northeast regions & 26.08 & 17.97 & 17.31 & 20.96 & 22.74 \\
\hline Southeast regions & 56.67 & 62.86 & 63.32 & 64.29 & 61.49 \\
\hline South region and Federal District & 17.25 & 19.17 & 19.38 & 14.74 & 15.77 \\
\hline
\end{tabular}

Source: 2008/2009 National Household Sample Survey. 
Table A7 Time allocated to domestic chores for household heads

\begin{tabular}{|c|c|c|c|c|c|}
\hline & Below 7 & $\begin{array}{r}\text { From } 7 \\
\text { to } 14\end{array}$ & $\begin{array}{r}\text { From } 14 \\
\text { to } 21\end{array}$ & $\begin{array}{r}\text { From } 21 \\
\text { to } 28\end{array}$ & $\begin{array}{r}28 \text { and } \\
\text { above }\end{array}$ \\
\hline \multicolumn{6}{|l|}{ Gender of h.h. } \\
\hline Male & 84.51 & 42.16 & 23.61 & 9.41 & 16.22 \\
\hline Female & 15.49 & 57.84 & 76.39 & 90.59 & 83.78 \\
\hline \multicolumn{6}{|l|}{ Age of h.h. } \\
\hline From 25 to 35 & 22.45 & 12.3 & 17.14 & 16.72 & 20.7 \\
\hline From 36 to 45 & 25.47 & 21.24 & 22.75 & 24.47 & 30.48 \\
\hline From 46 to 55 & 23.46 & 20.6 & 26.17 & 25.96 & 28.49 \\
\hline 56 and over & 28.63 & 45.86 & 33.94 & 32.85 & 20.33 \\
\hline \multicolumn{6}{|l|}{ Schooling level of h.h. } \\
\hline Less than 8 years & 38.88 & 54.15 & 51.99 & 52.07 & 40.97 \\
\hline From 8 to 10 & 14.89 & 7.66 & 13.81 & 12.54 & 17.45 \\
\hline High school & 29.44 & 21.3 & 20.17 & 24.44 & 32.7 \\
\hline Beyond high school & 16.8 & 16.89 & 14.02 & 10.95 & 8.88 \\
\hline \multicolumn{6}{|l|}{ Working status of h.h. } \\
\hline Employed & 78.91 & 74.67 & 66.02 & 55.92 & 35.17 \\
\hline Unemployed or Retired & 21.09 & 25.33 & 33.98 & 44.08 & 64.83 \\
\hline \multicolumn{6}{|l|}{ Household Children } \\
\hline No children & 30.59 & 44.07 & 35.98 & 23.2 & 22.46 \\
\hline All under 14 & 27.95 & 12.1 & 19.78 & 24.1 & 28.67 \\
\hline At least one over 14 & 41.46 & 43.83 & 44.25 & 52.7 & 48.87 \\
\hline \multicolumn{6}{|l|}{ Place of residence } \\
\hline North and Northeast regions & 20.25 & 25.68 & 27.25 & 30.75 & 22.76 \\
\hline Southeast regions & 63.39 & 56.71 & 52.79 & 52.13 & 62.57 \\
\hline South region and Federal District & 16.36 & 17.62 & 19.96 & 17.12 & 14.68 \\
\hline
\end{tabular}

Source: National Household Sample Survey 2008/2009. 


\section{Appendix B: Descriptive statistics for each cluster}

Table B1 shows the centroids for each cluster regarding each variable. The values range from 0 to 1 and resemble the results presented in table 1 .

Table B1 Clusters centroids

\begin{tabular}{l|r|r|r|rr}
\hline \multirow{2}{*}{ Variable } & \multicolumn{4}{r}{ Clusters } \\
\cline { 2 - 7 } & $\mathbf{1}$ & $\mathbf{2}$ & $\mathbf{3}$ & $\mathbf{4}$ & $\mathbf{5}$ \\
\hline Time allocated to working/commuting & 0.82 & 0.77 & 0.00 & 0.00 & 0.80 \\
\hline Time allocated to domestic chores & 0.18 & 0.37 & 0.46 & 0.47 & 0.24 \\
\hline Direct expenditures & 0.58 & 0.00 & 0.14 & 0.01 & 0.04 \\
\hline Total expenditures & 0.78 & 0.27 & 0.72 & 0.02 & 0.73 \\
\hline
\end{tabular}

Source: Own calculation.

Table B2 compares the five clusters by gender, age, schooling level, household composition, and place of residence. Cluster 1 characterized mostly males, younger and slightly more educated household heads, who lived in households without children and resided in the Southeast region. The variables for gender and place of residence were especially significant. In short, cluster 1 primarily represented households headed by men from the Southeast. Notice, from the results of tables 1 and 2, that this profile characterized workers who spent quite a large amount directly on culture. Cluster 2 was mostly composed of older women with lower levels of education, living in childless households, especially from the Southeast. Synthesizing with the results of table 1: these are older unskilled female workers who do not spend much on culture. Cluster 3 membership included slightly older household heads, with no other remarkable difference when compared to the total. This group did not work, but spent reasonable amounts on culture, probably because they do not face substantial income and time constraints. Cluster 4 characterized mostly male household heads, aged between 36 and 45, with 8 to 11 years of formal education, who lived with small children, and mostly lived in the North or Northeast regions. They did not work nor spend much on culture, probably due to income scarcity and low levels of cultural capital. Cluster 5 had a similar distribution to the total, though they were a little younger and more educated. They were workers who spent a reasonable amount on culture. 
Table B2 Descriptive statistics for each cluster

\begin{tabular}{|c|c|c|c|c|c|c|}
\hline \multirow[t]{2}{*}{ Variable } & \multicolumn{5}{|c|}{ Cluster } & \multirow[t]{2}{*}{ Total } \\
\hline & 1 & 2 & 3 & 4 & 5 & \\
\hline \multicolumn{7}{|l|}{ Gender of h.h. } \\
\hline$\%$ Female & 30.9 & 79.2 & 55.0 & 40.0 & 53.3 & 49.6 \\
\hline \multicolumn{7}{|l|}{ Age of h.h. } \\
\hline From 25 to 35 & 27.7 & 16.7 & 16.3 & 22.5 & 26.3 & 22.3 \\
\hline From 36 to 45 & 25.5 & 8.3 & 19.4 & 45.0 & 30.3 & 25.7 \\
\hline From 46 to 55 & 27.7 & 29.2 & 30.0 & 30.0 & 24.3 & 27.7 \\
\hline 56 and over & 19.1 & 45.8 & 34.4 & 2.5 & 19.1 & 24.3 \\
\hline \multicolumn{7}{|l|}{ Schooling level of h.h. } \\
\hline Less than 8 years & 29.8 & 25.0 & 32.5 & 25.0 & 23.7 & 28.1 \\
\hline From 8 to 10 & 19.1 & 54.2 & 23.8 & 32.5 & 24.3 & 25.3 \\
\hline High school & 24.5 & 16.7 & 24.4 & 37.5 & 27.0 & 26.0 \\
\hline Beyond high school & 26.6 & 4.2 & 19.4 & 5.0 & 25.0 & 20.6 \\
\hline \multicolumn{7}{|l|}{ Household Children } \\
\hline No children & 30.9 & 45.8 & 37.5 & 32.5 & 36.8 & 36.0 \\
\hline All under 14 & 30.9 & 37.5 & 23.1 & 45.0 & 27.6 & 28.7 \\
\hline At least one over 14 & 38.3 & 16.7 & 39.4 & 22.5 & 35.5 & 35.3 \\
\hline \multicolumn{7}{|l|}{ Place of residence } \\
\hline North and Northeast regions & 30.9 & 33.3 & 32.5 & 42.5 & 35.5 & 34.0 \\
\hline Southeast regions & 42.6 & 41.7 & 33.1 & 30.0 & 27.6 & 33.4 \\
\hline South region and Federal District & 26.6 & 25.0 & 34.4 & 27.5 & 36.8 & 32.6 \\
\hline
\end{tabular}

Source: Own calculation. 